\title{
Nitrogen Fixation by Myxophyceae from Marine Environments
}

\author{
By W. D. P. STEWART \\ Department of Botany, Westfield College, University of London \\ SUMMARY
}

Two blue-green algae from marine environments, Calothrix scopulorum and Nostoc entophytum, vigorously fixed ${ }^{15} \mathrm{~N}$-labelled nitrogen in artificial sea-water free from combined nitrogen and, rather faster, in natural seawater. A proportion of the nitrogen fixed was liberated into the medium. After a 7-day exposure period the extracellular nitrogen had a lower enrichment with ${ }^{15} \mathrm{~N}$ than the intracellular nitrogen. Fixation rates were not markedly affected by large variations in salinity of the medium. Calothrix was more resistant to changes in salinity than was Nostoc. Fixation in sea-water collected at various seasons was highest in January samples and lowest in July samples; additions of phosphate and of trace elements to the latter stimulated fixation. Ammonium-nitrogen did not inhibit fixation completely. It is probable that these species fix some nitrogen in Nature.

\section{INTRODUCTION}

Stewart $(1962,1963)$ reported on the basis of long-term growth analyses that the two blue-green algae Calothrix scopulorum and Nostoc entophytum isolated from marine environments fix atmospheric nitrogen and liberate a proportion of the nitrogen fixed into the medium. This extracellular nitrogen did not appear to be due to cell autolysis. It was felt desirable to confirm these data using the more sensitive and more convincing isotopic method employing ${ }^{15} \mathrm{~N}$, and to determine whether these processes are likely to occur in Nature. One factor which may be important is the nutritional status of the environment for there is evidence that this fluctuates sufficiently at various seasons of the year to affect the metabolism of many if not all marine algae (see, for example, Black \& Dewar, 1949). Combined nitrogen in the environment may also inhibit or completely suppress fixation and it is important to determine whether it is ever likely to do so in marine habitats. As the algae under investigation are abundant on the upper littoral and supra-littoral fringe of the seashore where large variations in salinity occur the effect of salinity on growth and fixation should be investigated. Finally from the point of view of further studies on these organisms the optimum conditions for growth and nitrogen fixation should be determined.

\section{METHODS}

Organisms. The algal strains employed were those used previously (Stewart, 1962, 1963,1964 ) and were available in pure culture. Inocula were prepared by shaking algae in the exponential growth phase with glass beads until a homogeneous suspension was obtained (Fogg, 1942). 
Sea-water. All samples used were collected from the shore at Gibraltar Point Nature Reserve, Lincolnshire. They were filtered through a Millipore HA membrane filter immediately upon collection and stored in darkness at $5^{\circ}$ until required.

Isotopic tests. Algae which had been grown routinely in nitrogen-free medium (Stewart, 1962), or in natural sea-water, were inoculated into fresh medium and exposed to an atmosphere enriched with ${ }^{15} \mathrm{~N}$. The gas mixture was prepared by the method of Bond \& Scott (1955). Gaseous nitrogen containing excess ${ }^{15} \mathrm{~N}$ was liberated by the reaction between sodium hypobromite and ${ }^{15} \mathrm{~N}$-enriched ammonium chloride in a nitrometer. Oxygen, carbon dioxide, and argon were obtained from cylinders (British Oxygen Company) to give a final mixture (v/v) of 70 \% A, $15 \%$ $\mathrm{N}_{2}, 10 \% \mathrm{O}_{2}$ and $5 \% \mathrm{CO}_{2}$. This was allowed to equilibrate for at least $2 \mathrm{hr}$ before being introduced into $40 \mathrm{ml}$. capacity test-tubes or conical flasks which contained the algal samples each generally of $1 \cdot 0-2.0 \mathrm{mg}$. nitrogen. The containers were attached to a manifold for gassing and the system was evacuated and flushed several times with argon before introducing the gas mixture until a pressure of 1 atmosphere was obtained. The containers were then shaken for several minutes, or continuously, to allow the medium to become saturated with the gas. The degree of enrichment of the gaseous nitrogen with ${ }^{15} \mathrm{~N}$ and the culture conditions during exposure varied with the experiment and are presented with the results. After exposure algae and media were separated through a Millipore HA membrane filter. Each sample was subjected to micro-Kjeldahl analysis using the catalyst mixture of Jacob (1959). Distillation was carried out in a Markham still and ammonia determined by nesslerization (Burris \& Wilson, 1957). ${ }^{15} \mathrm{~N}$ data were obtained by mass spectrometer (Associated Electrical Industries, Type MS 3) assay.

Long-term experiments. The effect of salinity concentration, and of ammoniumnitrogen, on fixation were investigated by inoculating the algae into $25 \mathrm{ml}$. samples of medium in $100 \mathrm{ml}$. conical flasks stoppered with cotton wool, and shaking continuously during the experimental period at 80 oscillations/min. Algae and media were separated by filtration through weighed Whatman no. 50 filter-paper, washed to remove media, and algal dry weights obtained by drying overnight at $95^{\circ}$. Total nitrogen was estimated as described above.

(1) Salinity experiments. The basal media employed are presented in Table 1. The desired salinities were obtained by diluting or concentrating solution 1 , solution 2 being maintained always at $1.0 \mathrm{ml}$./1. of final medium. Before inoculation the algae were transferred through six changes of distilled water to minimize carry-over of the original medium, algae and media being separated by centrifugation at each transfer. Aliquots of inoculum were added to 15 flasks at each of the following salinity levels: $0 \cdot 1,1 \cdot 0,2 \cdot 0,3 \cdot 5,4.5,6.0$ and $10.6 \%(w / v)$, and the contents of triplicate flasks at each treatment harvested every 3 days over a 15-day period and dry-weight data obtained as above.

(2) Combined nitrogen experiments. The effect of combined nitrogen on fixation was studied using a modification of the method of Stewart \& Bond (1961) for higher plants. Triplicate flasks, containing $50 \mathrm{mg}$./l. of ${ }^{15} \mathrm{~N}$-enriched ammonium chloride, were inoculated with algae and placed under alternating periods of $18 \mathrm{hr}$ light (mean intensity 390 foot-candles) and $6 \mathrm{hr}$ darkness. The salinity of the medium was $3.5 \%(\mathrm{w} / \mathrm{v})$ (above), mean temperature $26^{\circ}$, and initial $\mathrm{pH} 8 \cdot 0$. During the 
14-day experimental period $\mathrm{pH}$ levels, salinity concentrations, and ammoniumnitrogen concentrations were maintained near to normal by the daily addition, when necessary, of sodium hydroxide, distilled water or ${ }^{15} \mathrm{~N}$-enriched ammonium chloride.

Table 1. Media used in preparation of various salinity levels

\begin{tabular}{|c|c|c|c|}
\hline \multicolumn{2}{|c|}{ Solution 1} & \multicolumn{2}{|c|}{ Solution 2} \\
\hline $\mathrm{NaCl}$ & $24.80 \mathrm{~g}$. & $\mathrm{K}_{2} \mathrm{HPO}_{4}$ & $0.25 \mathrm{~g}$. \\
\hline $\mathrm{MgCl}_{2} \cdot 6 \mathrm{H}_{2} \mathrm{O}$ & $10.89 \mathrm{~g}$. & Fe citrate & $0.01 \mathrm{~g}$. \\
\hline $\mathrm{CaCl}_{2}$ & $1 \cdot 19 \mathrm{~g}$. & Citric acid & $0.01 \mathrm{~g}$ \\
\hline $\mathrm{K}_{2} \mathrm{SO}_{4}$ & $0.95 \mathrm{~g}$. & $\mathrm{Fe}$ (as chloride) & $0.40 \mathrm{mg}$. \\
\hline $\mathrm{Na}_{2} \mathrm{SO}_{4} .10 \mathrm{H}_{2} \mathrm{O}$ & $7 \cdot 30 \mathrm{~g}$. & Mn (as chloride) & $0 \cdot 10 \mathrm{mg}$. \\
\hline Distilled water & $999 \mathrm{ml}$. & Mo (as Na salt) & $0.10 \mathrm{mg}$. \\
\hline & & B (as boric acid) & $0.10 \mathrm{mg}$. \\
\hline & & $\mathrm{Cu}$ (as sulphate) & $0.01 \mathrm{mg}$. \\
\hline & & $\mathrm{Zn}$ (as sulphate) & $0.01 \mathrm{mg}$. \\
\hline & & Distilled water & $1.0 \mathrm{ml}$. \\
\hline
\end{tabular}

\section{RESULTS}

Tests for fixation of elemental nitrogen and for liberation of fixed nitrogen into the medium. In initial tests the algae were inoculated into $10 \mathrm{ml}$. samples of nitrogenfree medium or April 1963 sea-water and $48 \mathrm{hr}$ later exposed to ${ }^{15} \mathrm{~N}$ for 7 days. The data (Table 2) show that Calothrix and Nostoc assimilate elemental nitrogen in both media, fixation in natural sea-water being greater.

Table 2. Assimilation of ${ }^{15} \mathrm{~N}$ by Calothrix and Nostoc cultured in nitrogen-free medium and in natural sea-zwater

\begin{tabular}{|c|c|c|c|}
\hline Alga & Medium & Sample & $\begin{array}{l}\text { Atom \% excess } \\
{ }^{15} \mathrm{~N} \text { in alga }\end{array}$ \\
\hline Calothrix & Artificial N-free & $\begin{array}{l}\mathbf{1} \\
\mathbf{2} \\
\mathbf{3}\end{array}$ & $\left.\begin{array}{l}7 \cdot 558 \\
9 \cdot 327 \\
7 \cdot 924\end{array}\right\}(8 \cdot 270)$ \\
\hline & Natural sea water & $\begin{array}{l}\mathbf{1} \\
\mathbf{2}\end{array}$ & $\left.\begin{array}{l}12 \cdot 105 \\
11 \cdot 762\end{array}\right\}(11 \cdot 934)$ \\
\hline Nostoc & Artificial N-free & $\begin{array}{l}1 \\
2 \\
3\end{array}$ & $\left.\begin{array}{l}8 \cdot 744 \\
8 \cdot 613 \\
8 \cdot 410\end{array}\right\}(8 \cdot 589)$ \\
\hline & Natural sea water & $\begin{array}{l}\mathbf{1} \\
\mathbf{2}\end{array}$ & $\left.\begin{array}{l}12 \cdot 312 \\
12 \cdot 446\end{array}\right\}(12 \cdot 379)$ \\
\hline
\end{tabular}

Period of exposure $=7$ days; labelling of gaseous $\mathrm{N}=17$ atom $\%{ }^{15} \mathrm{~N}$; volume of medium $=$

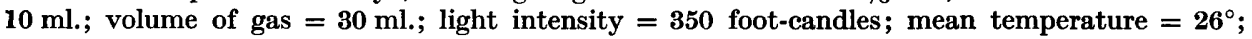
mean ${ }^{15} \mathrm{~N}$ content of inocula $=\mathbf{0} \cdot \mathbf{3 7 2}$ atom $\%$; figures in parentheses are means.

Data on growth in nitrogen-free medium at various salinity levels (Fig. 1) indicate that nitrogen fixation occurs over wide salinity ranges. There is no well-defined optimum salinity level for either species. Growth of Calothrix is not significantly different $(\boldsymbol{P}=\mathbf{0 . 0 5}$ level $)$ at salinities of $0.1-4.5 \%(\mathrm{w} / \mathrm{v})$, although there is some evidence of slightly better growth at $1 \cdot 0-3 \cdot 5 \%(\mathrm{w} / \mathrm{v})$. At $6.0 \%(\mathrm{w} / \mathrm{v})$ growth is significantly poorer than at lower salinities. At $10.6 \%(\mathrm{w} / \mathrm{v})$ no increase in dry weight occurred during the 15-day period, although such cultures resume normal growth if the salinity is reduced to $6.0 \%(\mathrm{w} / \mathrm{v})$ or lower. The Nostoc growth rates are similar at $1 \cdot 0-3.5 \%(\mathrm{w} / \mathrm{v})$, but again there is evidence of slightly better growth near to $2.0 \%(\mathrm{w} / \mathrm{v})$. Growth at $4.5 \%(\mathrm{w} / \mathrm{v})$ is significantly poorer than at the lower 
levels. Little growth occurred at $6.0 \%(w / v)$, while at $10 \cdot 6 \%(w / v)$ no increase in dry weight occurred. Cultures exposed to the latter treatment fail to multiply on reduction of the salinity level to $4.5 \%(\mathrm{w} / \mathrm{v})$ or lower, indicating that exposure to such a high salinity for such a period is toxic to the algae.

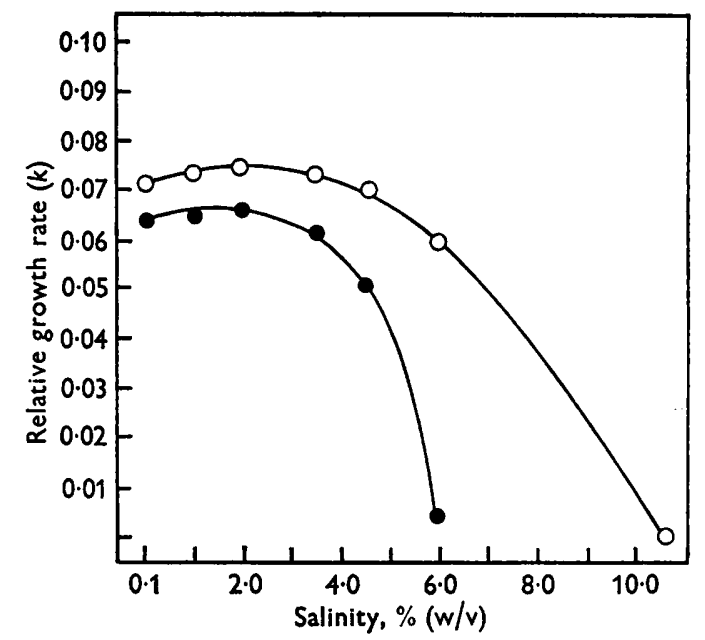

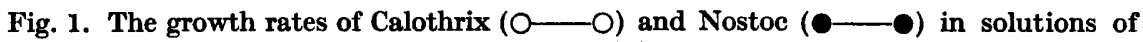
differing salinity.

Table 3. Fixation and liberation of ${ }^{15} \mathrm{~N}$ by Calothrix and Nostoc

\begin{tabular}{|c|c|c|c|c|c|}
\hline Alga & Medium & Sample & $\begin{array}{c}\text { Atom } \% \\
\text { excess }{ }^{15} \mathbf{N} \\
\text { in alga }\end{array}$ & $\begin{array}{l}\text { Atom } \% \\
\text { excess }{ }^{15} \mathrm{~N} \\
\text { in medium }\end{array}$ & $\begin{array}{c}\text { Atom } \% \text { excess }{ }^{15} \mathbf{N} \\
\text { in medium as } \% \text { of } \\
\text { atom } \% \text { excess }{ }^{15} \mathbf{N} \\
\text { in alga }\end{array}$ \\
\hline Calothrix & Artificial N-free & $\begin{array}{l}\mathbf{1} \\
\mathbf{2} \\
\mathbf{3}\end{array}$ & $\left.\begin{array}{l}0 \cdot 352 \\
0 \cdot 401 \\
0 \cdot 470\end{array}\right\}(0 \cdot 408)$ & $\left.\begin{array}{l}0 \cdot 103 \\
0 \cdot 310 \\
0 \cdot 148\end{array}\right\}(0 \cdot 187)$ & $\left.\begin{array}{l}29 \\
77 \\
32\end{array}\right\}$ (46) \\
\hline \multirow{3}{*}{ Nostoc } & Natural sea-water & $\begin{array}{l}\mathbf{1} \\
\mathbf{2} \\
\mathbf{3}\end{array}$ & $\left.\begin{array}{l}0 \cdot 794 \\
0 \cdot 826 \\
0 \cdot 963\end{array}\right\}(0 \cdot 861)$ & $\left.\begin{array}{l}0 \cdot 321 \\
0 \cdot 288 \\
0 \cdot 443\end{array}\right\}(0 \cdot 351)$ & $\left.\begin{array}{l}40 \\
35 \\
46\end{array}\right\}(40)$ \\
\hline & Artificial N-free & $\begin{array}{l}\mathbf{1} \\
\mathbf{2} \\
\mathbf{3}\end{array}$ & $\left.\begin{array}{l}0 \cdot 356 \\
0 \cdot 462 \\
0.495\end{array}\right\}(0 \cdot 438)$ & $\left.\begin{array}{l}0 \cdot 135 \\
0 \cdot 194 \\
0 \cdot 213\end{array}\right\}(0 \cdot 181)$ & $\left.\begin{array}{l}38 \\
42 \\
43\end{array}\right\}(41)$ \\
\hline & Natural sea-water & $\begin{array}{l}1 \\
2 \\
3\end{array}$ & $\left.\begin{array}{l}0.514 \\
0.414 \\
0.383\end{array}\right\}(0.437)$ & $\left.\begin{array}{l}0 \cdot 303 \\
0 \cdot 158 \\
0 \cdot 158\end{array}\right\}(0 \cdot 206)$ & $\left.\begin{array}{l}59 \\
38 \\
41\end{array}\right\}(46)$ \\
\hline
\end{tabular}

Period of exposure $=7$ days; labelling of gaseous $\mathrm{N}=3$ atom $\%{ }^{15} \mathrm{~N}$; volume of medium $=$ $25 \mathrm{ml}$; ; volume of gas $=15 \mathrm{ml}$.; light intensity $=350$ foot-candles; mean temperature $=24^{\circ}$; mean ${ }^{15} \mathrm{~N}$ content of inocula $=\mathbf{0 . 3 7 0}$ atom $\%$; figures in parentheses are means.

Once fixation was established data on the liberation of extracellular nitrogen were obtained. The algae were transferred into $25 \mathrm{ml}$. samples of fresh medium and immediately exposed to ${ }^{15} \mathrm{~N}$, after which they were gently shaken during the exposure period. The data (Table 3) show that fixed nitrogen is liberated into nitrogen-free medium and into sea-water. The extracellular nitrogen has a lower labelling with ${ }^{15} \mathrm{~N}$ than the intracellular nitrogen. 
Assimilation of ${ }^{15} \mathrm{~N}$ in sea-water samples from different seasons. Tests which employ long exposure periods, while necessary to determine whether fixation occurs, have the disadvantage in that during exposure the medium may change as a result of algal metabolism. This can be overcome to some extent by inoculating a small algal sample into a relatively large volume of sea-water and employing a short exposure period. This method was employed in tests for fixation by algae inoculated into seawaters collected in July 1962, October 1962, January 1963 and April 1963. The algae were transferred every $24 \mathrm{hr}$, employing the methods detailed earlier, into fresh $25 \mathrm{ml}$. samples of these sea-waters during the 7 days before exposure to ${ }^{15} \mathrm{~N}$. The data (Table 4) show that both algae assimilate gaseous nitrogen in all sea-

Table 4. Assimilation of ${ }^{15} \mathrm{~N}$ by Calothrix and Nostoc when grown in sea-waters collected at various seasons of the year

\begin{tabular}{|c|c|c|c|}
\hline \multirow[b]{2}{*}{ Sea-water } & \multirow[b]{2}{*}{ Sample } & \multicolumn{2}{|c|}{ Atom $\%$ excess ${ }^{15} \mathrm{~N}$ in alga } \\
\hline & & Calothrix & Nostoc \\
\hline January 1963 & $\begin{array}{l}1 \\
2\end{array}$ & $\left.\begin{array}{l}0 \cdot 254 \\
0 \cdot 233\end{array}\right\}(0 \cdot 244)$ & $\left.\begin{array}{l}0 \cdot 203 \\
0 \cdot 193\end{array}\right\}(0 \cdot 198)$ \\
\hline April 1963 & $\begin{array}{l}1 \\
2\end{array}$ & $\left.\begin{array}{l}0.189 \\
0.207\end{array}\right\}(0 \cdot 198)$ & $\left.\begin{array}{l}0 \cdot 182 \\
0 \cdot 186\end{array}\right\}(0 \cdot 184)$ \\
\hline July 1962 & $\begin{array}{l}\mathbf{1} \\
\mathbf{2}\end{array}$ & $\left.\begin{array}{l}0 \cdot 184 \\
0 \cdot 176\end{array}\right\}(0 \cdot 180)$ & $\left.\begin{array}{l}0 \cdot 165 \\
0 \cdot 152\end{array}\right\}(0 \cdot 159)$ \\
\hline October 1962 & $\begin{array}{l}\mathbf{1} \\
\mathbf{2}\end{array}$ & $\left.\begin{array}{l}0.211 \\
0.202\end{array}\right\}(0 \cdot 207)$ & $\left.\begin{array}{l}0 \cdot 192 \\
0 \cdot 186\end{array}\right\}(0 \cdot 189)$ \\
\hline
\end{tabular}

Period of exposure $=3 \mathrm{hr}$; labelling of gaseous $\mathbf{N}=30$ atom $\%{ }^{15} \mathrm{~N}$; volume of medium $=$ $25 \mathrm{ml}$; ; volume of gas $=15 \mathrm{ml}$; light intensity $=600$ foot-candles; mean temperature $=25^{\circ}$; mean ${ }^{15} \mathrm{~N}$ content of inocula $=0.370$ atom $\%$; figures in parentheses are means.

Table 5. The effect of phosphate and of trace elements on nitrogen fixation by Calothrix and Nostoc in natural sea-rvater

Alga

Treatment

Calothrix

No addition
+ phosphate
+ trace elements
+ phosphate and trace elements

Nostoc

$$
\begin{aligned}
& \text { No addition } \\
& + \text { phosphate } \\
& + \text { trace elements } \\
& + \text { phosphate and trace elements }
\end{aligned}
$$

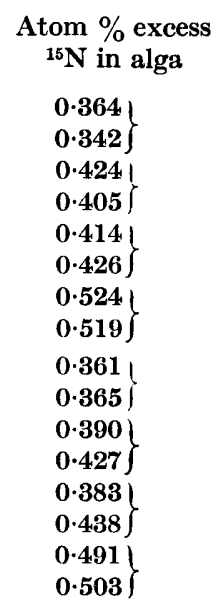

${ }^{15} \mathrm{~N}$ enrichment over alga grown in untreated sea water

$$
\begin{aligned}
& - \\
& +0.062 \\
& +0.067 \\
& +0.169 \\
& - \\
& +0.046 \\
& +0.048 \\
& +0.134
\end{aligned}
$$

Period of exposure $=3 \mathrm{hr}$; labelling of gaseous $\mathrm{N}=60$ atom $\%{ }^{15} \mathrm{~N}$; volume of medium $=$ $25 \mathrm{ml}$; ; volume of gas $=15 \mathrm{ml}$; light intensity $=600$ foot-candles; mean temperature $=25^{\circ}$; mean ${ }^{15} \mathrm{~N}$ content of inocula $=0.372$ atom $\%$. 
waters, fixation being greatest in January samples and lowest in July samples. Fixation in April and October samples was of the same order. To determine whether fixation in July samples could be improved, additions of $50 \mathrm{mg}$./1. of $\mathrm{K}_{2} \mathrm{HPO}_{4}$ and of trace elements similar to those used previously (Stewart, 1962) apart from a further addition of $60 \mu \mathrm{g}$./l. of $\mathrm{Co}\left(\right.$ as $\mathrm{CoCl}_{2}$ ) were made. The results (Table 5) show that fixation was increased on the addition of either supplement, the addition of both simultaneously resulting in greater fixation than either alone.

The effect of combined nitrogen on fixation of elemental nitrogen. The inorganic combined nitrogen concentrations in coastal waters are generally in the region of 10$100 \mu \mathrm{g}$./l. (Harvey, 1960), but blue-green algae often predominate where combined nitrogen is relatively high (e.g. areas rich in bird excreta, polluted bays and estuaries). The algae were therefore grown in the presence of $50 \mathrm{mg}$./l. of ammonium-nitrogen, a concentration unlikely to be exceeded in Nature.

The data obtained (Table 6) show that in the presence of such a concentration nitrogen fixation by Calothrix and Nostoc is inhibited by approximately $86 \%$ and $90 \%$ respectively.

Table 6. The effect of ammonium-nitrogen on fixation of elemental nitrogen by Calothrix and Nostoc

\begin{tabular}{|c|c|c|c|c|c|c|}
\hline Alga & Sample & $\begin{array}{c}\text { Total } \mathbf{N} \\
\text { assimilated } \\
\text { by alga } \\
(\mu \mathrm{g} .)\end{array}$ & $\begin{array}{c}\text { Atom } \%{ }^{15} \mathrm{~N} \\
\text { in } N \\
\text { assimilated } \\
\text { by alga }\end{array}$ & $\begin{array}{l}\mathrm{N} \text { in alga } \\
\text { from } \\
\text { medium } \\
(\mu \mathrm{g} .)\end{array}$ & $\begin{array}{c}\mathbf{N} \text { in alga } \\
\text { from } \\
\text { atmosphere } \\
(\mu \mathrm{g} .)\end{array}$ & $\begin{array}{c}\text { Atmospheric } \mathbf{N} \\
\text { fixed as } \\
\text { percentage of } \\
\text { total } \mathbf{N} \\
\text { assimilated }\end{array}$ \\
\hline \multirow[t]{3}{*}{ Calothrix } & $\mathbf{1}$ & 788 & 4.590 & 691 & 97 & $12 \cdot 3$ \\
\hline & 2 & 960 & 4.351 & 798 & 162 & $16.9\}(13.9)$ \\
\hline & $\mathbf{3}$ & 828 & 4.585 & 725 & 103 & $12 \cdot 4\}$ \\
\hline \multirow[t]{3}{*}{ Nostoc } & 1 & 1102 & 4.677 & 984 & 118 & $10 \cdot 7)$ \\
\hline & 2 & 1113 & $4 \cdot 865$ & 1034 & 79 & $(9 \cdot 8)$ \\
\hline & 3 & 1189 & $4 \cdot 625$ & 1050 & 139 & $11 \cdot 7)$ \\
\hline
\end{tabular}

$\mathrm{N}$ in Calothrix inoculum $=50 \mu \mathrm{g} . ;{ }^{15} \mathrm{~N}$ content of Calothrix inoculum $=0.372$ atom $\% ; \mathrm{N}$ in Nostoc inoculum $=132 \mu \mathrm{g}$; $\mathbf{N}$ content of Nostoc inoculum $=0.370$ atom $\% ;{ }^{15} \mathrm{~N}$ content of $\mathrm{NH}_{\mathbf{4}}-\mathrm{N}$ supplied $=\mathbf{5} \cdot 236$ atom \%; figures in parentheses are means.

\section{DISCUSSION}

It is obvious that both Calothrix and Nostoc assimilate elemental nitrogen, thus confirming the long-term growth analyses of Stewart (1962, 1963). The data on fixation in natural sea-water suggest that both species may contribute appreciable quantities of fixed nitrogen to their natural environments. The greater fixation in natural sea-water compared with artificial medium is not a salinity effect, for Fig. 1 shows growth at $0.6 \%(\mathrm{w} / \mathrm{v})$ to be similar to that at $3.5 \%(\mathrm{w} / \mathrm{v})$. It may be a result of organic material in natural sea-water stimulating growth, although the algae have been grown routinely for the past 5 years in purely mineral medium and, like other nitrogen-fixing Myxophyceae (Fogg, 1956), appear to have no organic growthfactor requirement. A second possibility is that the combined nitrogen in natural sea-water reduces the lag phase which occurs when these species are transferred to nitrogen-free medium.

The data in Fig. 1 indicate that the salinity levels generally occurring in Nature 
should not markedly affect growth and fixation. Calothrix indeed appears to be one of the most euryhaline algae isolated in pure culture. Its ability to withstand high salinity without growing is a feature noted for other algae, e.g. Peridinium balticum (Provasoli, McLaughlin \& Pinter, 1954). Extrapolation of the Nostoc data indicates that this alga should grow in freshwater habitats and its occurrence there has been noted (Bornet \& Flahault, 1888). The ability of certain blue-green algae to fix nitrogen both in marine and freshwater environments is probably a more common phenomenon than generally realized. In addition to the above data Allen (1958) reported that the freshwater blue-green algae Anabaena cylindrica, Calothrix parietina and various Nostoc species fixed nitrogen at salinities approaching those of natural sea-water. Fay \& Fogg (1962) reported similarly for Chlorogloea fritschii.

The tolerance of Calothrix and Nostoc to large salinity changes accords with their niche on the supra-littoral fringe of the seashore. Ércegovic (1930) recorded growth of Calothrix scopulorum in the field at salinities of $0 \cdot 4-3.8 \%(\mathrm{w} / \mathrm{v})$ but not where salinities varied from 0 to $28.3 \%(w / v)$. The present data suggest that lack of growth in the latter habitat may be due more to the high salinity levels encountered rather than to the low salinities. Thus, an increase in salinity may be partly responsible for the disappearance in summer of a large proportion of the British marine blue-green algal flora.

The data on production of ${ }^{15} \mathrm{~N}$-labelled extracellular nitrogen indicate that this is a general phenomenon associated with these species. The lower labelling of the medium shows that all the nitrogen liberated is not specifically associated with the fixation process, this suggestion being supported by the findings (Fogg, 1952; McCalla, 1963) that non-nitrogen-fixing algae also liberate extracellular nitrogen. Zelitch, Rosenblum, Burris \& Wilson (1953) found that Clostridium pasteurianum liberated extracellular nitrogen more highly enriched with ${ }^{15} \mathrm{~N}$ than the intracellular nitrogen after $\mathbf{4 5} \mathrm{min}$. exposure to the isotope. The labelling of extracellular nitrogen by the present algae during the early stages of fixation is being investigated.

All the sea-water samples tested supported nitrogen fixation (Table 4); thus throughout the year the marine environment should allow both algae to fix nitrogen. The lower fixation in July samples may be correlated with the poorer supply of inorganic nutrients in the sea during the summer months. Inorganic nutrients limiting marine productivity are phosphorus, nitrogen and trace elements (Harvey, 1960). Thus, with nitrogen-fixing organisms nitrogen should not be limiting providing the other essential nutrients are in adequate supply. The Table 5 data show that in sea-water phosphate and at least some of the trace elements are present in suboptimal concentrations for fixation, a conclusion also arrived at by Allen (1963) from studies on algal nitrogen fixation in artificial sea-water. The concentrations presently employed are not necessarily optimum and probably greater stimulation of fixation by these elements may be achieved.

It appears to be a general phenomenon that combined nitrogen (particularly ammonium-nitrogen) inhibits nitrogen fixation. This suggestion is supported by the data in Table 6 . The incomplete inhibition of fixation may be due in part to the high salinity of the medium $(3.5 \%, w / v)$, for there is evidence (Stewart, unpublished) that the toxic effect of high ammonium-nitrogen levels on growth of these organisms may be reduced by increasing the salinity of the medium. 
These data suggest that in Nature some fixation of nitrogen is likely to be associated with these species.

The author is indebted to Professor G. E. Fogg for his encouragement and helpful advice, to Dr P. Fay for direction in the use of the mass spectrometer and to Miss Gail Hepburn for technical assistance. The mass spectrometer used was purchased with the aid of a grant to the Department from the Department of Scientific and Industrial Research. The award of a grant-in-aid from The Royal Society is also gratefully acknowledged.

\section{REFERENCES}

Allen, M. B. (1958). An approach to the problem of marine nitrogen fixation. Abstr. 3rd int. Seareed Symp. p. 23.

Allen, M. B. (1963). Nitrogen fixing organisms in the sea. In Symp. on Marine Microbiology. Ed. by C. H. Oppenheimer, p. 85. Illinois: C. C. Thomas.

Black, W. A. P. \& Dewar, E. T. (1949). Correlation of some of the physical and chemical properties of the sea with the chemical constitution of the algae. J. mar. biol. Ass. U.K. 28, 673 .

Bond, G. \& Scotr, G. D. (1955). An examination of some symbiotic systems for fixation of nitrogen. Ann. Bot., Lond., N.S. 19, 67.

Bornet, E. \& Frahault, C. (1888). Revision des Nostocacées hétérocystées contenues dans les principaux herbiers de France, 4. Annls. Sci. nat. Bot. 7, 171.

Burris, R. H. \& Wilson, P. W. (1957). Methods for measurement of nitrogen fixation. In Methods in Enzymology, 4, 355. New York: Academic Press.

ÉrCEgovic, A. (1930). Sur la tolérance des Cyanophycées vis-à-vis des variations brusques de la salinité de l'eau de mer. Acta bot. Inst. bot., Zagreb, 5, 48.

FAY, P. \& FoGG, G. E. (1962). Studies on nitrogen fixation by blue-green algae. III. Growth and nitrogen fixation in Chlorogloea fritschii Mitra. Arch. Mikrobiol. 42, 310.

FoGG, G. E. (1942). Studies on nitrogen fixation by blue-green algae, I. Nitrogen fixation by Anabaena cylindrica Lemm. J. exp. Biol. 19, 78.

FogG, G. E. (1952). The production of extracellular nitrogenous substances by a bluegreen alga. Proc. roy. Soc. B, 139, 372.

Fogg, G. E. (1956). Nitrogen fixation by photosynthetic organisms. A. Rev. Pl. Physiol. $7,51$.

Harvey, H. W. (1960). The Chemistry and Fertility of Sea Waters, pp. 240. Cambridge University Press.

$\mathrm{J}_{\mathrm{ACOB}}$, S. (1959). Determination of nitrogen in proteins by means of indanetrionehydrate. Nature, Lond. 183, 262.

McCalla, D. R. (1963). Accumulation of extracellular amino acids by Euglena gracilis. J. Protozool. 10, 491.

Provasoli, L., Mclaughlin, J. J. A. \& Pintner, I. J. (1954). Relative and limiting concentrations of major mineral constituents for the growth of algae flagellates. Trans. N.Y. Acad.Sci. 16, 412.

STEwart, W. D. P. (1962). Fixation of elemental nitrogen by marine blue-green algae. Ann. Bot., Lond. N.S. 26, 439.

Stewart, W. D. P. (1963). Liberation of extracellular nitrogen by two nitrogen fixing blue-green algae. Nature, Lond. 200, 1020.

STEWART, W. D. P. (1964). The effect of available nitrate and ammonium nitrogen on the growth of two nitrogen fixing blue-green algae. J. exp. Bot. 43, 138.

Stewar', W. D. P. \& Bond, G. (1961). The effect of combined nitrogen on fixation of elemental nitrogen by Alnus and Myrica. Plant \& Soil, 14, 347.

Zititch, I., Rosenblum, E. D., Burris, R. H. \& Wilson, P. W. (1953). Isolation of the key intermediate in biological nitrogen fixation by Clostridium. J. biol. Chem. 191, 295. 